\title{
Accelerated Exposure Tests of Encapsulated Si Solar Cells and Encapsulation Materials
}

F.J. Pern and S.H. Glick

National Renewable Energy Laboratory

Presented at the National Center for

Photovoltaics Program Review Meeting

Denver, Colorado

September 8-11, 1998

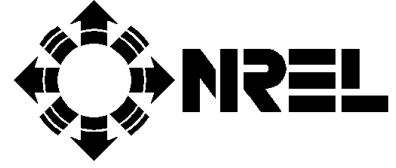

National Renewable Energy Laboratory 1617 Cole Boulevard Golden, Colorado 80401-3393

A national laboratory of the U.S. Department of Energy Managed by Midwest Research Institute for the U.S. Department of Energy under contract No. DE-AC36-83CH10093

Work performed under task number PV806201

October 1998 


\begin{abstract}
NOTICE
This report was prepared as an account of work sponsored by an agency of the United States government. Neither the United States government nor any agency thereof, nor any of their employees, makes any warranty, express or implied, or assumes any legal liability or responsibility for the accuracy, completeness, or usefulness of any information, apparatus, product, or process disclosed, or represents that its use would not infringe privately owned rights. Reference herein to any specific commercial product, process, or service by trade name, trademark, manufacturer, or otherwise does not necessarily constitute or imply its endorsement, recommendation, or favoring by the United States government or any agency thereof. The views and opinions of authors expressed herein do not necessarily state or reflect those of the United States government or any agency thereof.
\end{abstract}

Available to DOE and DOE contractors from:

Office of Scientific and Technical Information (OSTI)

P.O. Box 62

Oak Ridge, TN 37831

Prices available by calling 423-576-8401

Available to the public from:

National Technical Information Service (NTIS)

U.S. Department of Commerce

5285 Port Royal Road

Springfield, VA 22161

703-605-6000 or 800-553-6847

or

DOE Information Bridge

http://www.doe.gov/bridge/home.html 


\title{
Accelerated Exposure Tests of Encapsulated Si Solar Cells and Encapsulation Materials
}

\author{
F. J. Pern and S. H. Glick \\ Engineering and Reliability Division, National Center for Photovoltaics \\ National Renewable Energy Laboratory, 1617 Cole Blvd., Golden, CO 80401
}

\begin{abstract}
We have conducted a series of accelerated exposure test (AET) studies for various crystalline-Si (c-Si) and amorphous-Si (a-Si) cell samples that were encapsulated with different superstrates, pottants, and substrates. Nonuniform browning patterns of ethylene vinyl acetate (EVA) pottants were observed for glass/EVA/glass-encapsulated c-Si cell samples under solar simulator exposures at elevated temperatures. The polymer/polymer-configured laminates with Tedlar or Tefzel did not discolor because of photobleaching reactions, but yellowed with polyester or nylon top films. Delamination was observed for the polyester/EVA layers on a-Si minimodules and for a polyolefin-based thermoplastic pottant at high temperatures. For all tested c-Si cell samples, irregular changes in the current-voltage parameters were observed that could not be accounted for simply by the transmittance changes of the superstrate/pottant layers. Silicone-type adhesives used under UV-transmitting polymer top films were observed to cause greater cell current/efficiency loss than EVA or polyethylene pottants.
\end{abstract}

\section{INTRODUCTION}

Reliable performance of photovoltaic (PV) modules with a 30-year service life requires that every module component and the entire assembly be durable without substantial degradation during the use period. Natural weathering testing for 20-30 years is impractical when a validation period of 2-5 years is desired for developing products with new encapsulation materials, processing methods, or both. Accordingly, artificial accelerated exposure testing (AET) has practical importance to meet this purpose. This work is the second report of our AET experiments to study issues about the reliability the PV materials and cells [1]. The objectives are to determine and separate the effects of optical degradation of the superstrate and pottant from the electrical degradation of cell components on the overall solar cell performance, to observe the degradation in adhesion of encapsulation materials, and to develop a data correlation methodology for the optical and electrical results. We used small-sized encapsulated solar cells that represent most of the features in a commercial-scale module. The "small-size" approach permits an economical way to test a large quantity of either nearly identical samples for statistical purposes or differently configured samples for ranking or comparison purposes. In this study, we also tested samples of cSi cell, a-Si minimodules, and a new pottant, respectively, for three PV manufacturers. 


\section{EXPERIMENTAL}

All of the samples studied were $5.1 \mathrm{~cm} \mathrm{x} 7.6 \mathrm{~cm}$ ( 2 in. $x 3$ in.) and the c-Si solar cells were $3 \mathrm{~cm} \times 3 \mathrm{~cm}$. (a) ECIS samples had a c-Si cell laminated between two 3.175-mmthick borosilicate plates with two layers of the commercial EVA formulation, A9918 or 15295. (b) Spire's samples had a c-Si solar cell, $125-\mu \mathrm{m}$ or 320- $\mu \mathrm{m}$ thick, laminated with $25-\mu \mathrm{m}$ Tedlar or Tefzel films using a thin layer EVA pottant or silicone adhesive [2]. (c) a-Si minimodules were $3.7 \mathrm{~cm}$ x $7.5 \mathrm{~cm}$ from a PV manufacturer and were rolllaminated with a thin polymer top-film and a thin encapsulating layer. (d) Samples of Evergreen Solar's polyolefin-based thermoplastic pottants (EGS) were laminated between two borosilicate plates. The type of cell, encapsulation materials, AET, systems employed, and conditions are indicated in the tables. The EGS samples were exposed side-by-side with ECIS samples in each AET test. The exposures were conducted in a laboratory with a relative humidity typically in the $20 \%-40 \%$ range. Insitu c-Si cell and EVA temperatures were measured by using two custom-made sensors that had five spatially-placed thermocouples under a 3-cm x 3-cm c-Si cell and one between two EVA layers that were encapsulated similarly to the ECIS samples. The samples were characterized periodically for transmittance, color indices, fluorescence, and/or current-voltage (I-V) parameters.

\section{RESULTS AND DISCUSSION}

Case 1. ECIS c-Si Cell Samples. For ECIS (and EGS) samples, Table 1 summarizes the type of AET, conditions, pottant types, and percentage changes in the I-V parameters, transmittance (\%T) integrated over the 290-792 nm and 290-1252 nm ranges, and yellowness index. The measurement error ranges and standard deviations are also included in the Table. The efficiency changes in the c-Si cell are irregular with respect to the AET type, conditions, and \%T changes! For the ECIS samples exposed in DSET CPS systems and in an oven, where EVA did not discolor, seven cells showed a net gain in short-circuit current density $\left(\mathrm{J}_{\mathrm{sc}}\right)$ or efficiency and two showed a net loss (within the measurement error range). Only one cell sample showed little change. For the cells exposed to a UV-enhanced solar simulator (UV-SS), the EVA gradually turned yellow-brown, but net efficiency gains are observed even though the $\% \mathrm{~T}$ shows a net loss of $9 \%-17 \%$. More obvious efficiency decreases corresponding, though not linearly or proportionally, to large $\% \mathrm{~T}$ losses are observed for those samples exposed to the fullspectrum solar simulator (FS-SS), where the EVA rapidly turned dark brown in $\sim 7-10$ days. Here, the monitored in-situ temperature of the c-Si cell was $\sim 125^{\circ} \mathrm{C}$, and it was $\sim 110^{\circ}-115^{\circ} \mathrm{C}$ for the EVA layer in the "optical" region. Nonuniform EVA browning was observed in both the UV-SS and FS-SS exposed samples, but was more profound in the FS-SS exposed samples. This resulted in a lower photocurrent from the cell perimeter region under darkly browned EVA and a higher photocurrent from the central region under less browned EVA. For comparison, a fairly uniform EVA browning was observed over the $10-\mathrm{cm} \times 10-\mathrm{cm}$ c-Si cells in field-degraded modules. 
TABLE 1. Change (\%) of I-V Parameters, Transmittance, and Yellowness Index for Encapsulated Si Cells and an EGS Pottant by AET Treatments

\begin{tabular}{|c|c|c|c|c|c|c|c|c|c|c|c|c|c|c|}
\hline $\begin{array}{l}\text { Sample } \\
\text { ID }\end{array}$ & $\begin{array}{l}\text { Super- } \\
\text { strate }\end{array}$ & $\begin{array}{l}\text { Pottant } \\
\text { Type }\end{array}$ & $\begin{array}{l}\text { Sub- } \\
\text { strate }\end{array}$ & $\begin{array}{l}\text { Time } \\
\text { (h) }\end{array}$ & $\begin{array}{l}V_{\text {oc }} \\
(\%)\end{array}$ & $\begin{array}{l}V_{\max } \\
(\%)\end{array}$ & $\begin{array}{l}\mathbf{J}_{\text {sc }} \\
(\%)\end{array}$ & $\begin{array}{l}\mathbf{J}_{\max } \\
(\%)\end{array}$ & $\begin{array}{l}\text { FF } \\
(\%)\end{array}$ & $\begin{array}{l}P_{\max } \\
(\%)\end{array}$ & $\begin{array}{l}\text { \%T } \\
(\%)\end{array}$ & $\begin{array}{c}\text { Rate } \\
(\% \mathrm{~T} / \mathrm{h})\end{array}$ & $\begin{array}{l}\text { Net YI } \\
\text { Change }\end{array}$ & $\begin{array}{l}\text { Rate } \\
\text { (YI/h) }\end{array}$ \\
\hline & \multirow{2}{*}{\multicolumn{4}{|c|}{$\begin{array}{l}\text { Measurement Error Range (+-\%): } \\
\text { Standard Deviation/Average (\%): }\end{array}$}} & 0.99 & 1.85 & 2.35 & 3.38 & 1.11 & 1.75 & 0.63 & & 4.79 & \\
\hline & & & & & 0.55 & 1.85 & 1.87 & 2.01 & 0.66 & 1.39 & 0.35 & & 3.23 & \\
\hline \multicolumn{7}{|c|}{ AET: Oven $/ 0 \mathrm{UV}$ sun $/ 85^{\circ} \mathrm{C}$} & \multicolumn{8}{|c|}{$(290-792 \mathrm{~nm})$} \\
\hline ECIS-03 & Boro ${ }^{1}$ & $15295 \mathrm{P}^{2}$ & Boro & 1581 & -0.58 & -3.08 & -2.88 & -2.38 & -2.04 & -5.38 & -0.72 & $-4.55 \mathrm{E}-2$ & 1.02 & $6.47 \mathrm{E}-4$ \\
\hline ECIS-07 & Boro & $15295 \mathrm{P}$ & Boro & 1216 & -0.14 & -3.34 & 11.70 & 9.00 & -5.60 & 5.30 & -2.23 & $-1.83 \mathrm{E}-1$ & 0.56 & $4.59 \mathrm{E}-4$ \\
\hline ECIS-19 & Boro & A9918P & Boro & 925 & 0.10 & 0.00 & 6.61 & 6.94 & 0.20 & 6.88 & -0.76 & $-8.21 \mathrm{E}-2$ & 0.19 & $2.08 \mathrm{E}-4$ \\
\hline EGS-07 & Boro & $\mathrm{EGS}^{3}$ & Boro & 1216 & & & & & & & -0.39 & $-3.17 \mathrm{E}-2$ & 0.36 & $2.96 \mathrm{E}-4$ \\
\hline EGS-08 & Boro & EGS & Boro & 1216 & & & & & & & -0.16 & $-1.34 \mathrm{E}-2$ & 0.33 & $2.74 \mathrm{E}-4$ \\
\hline \multicolumn{15}{|c|}{ 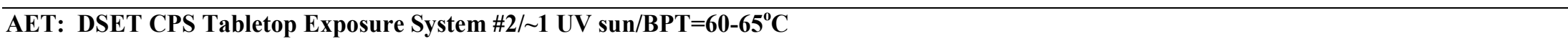 } \\
\hline ECIS-04 & Boro & $15295 \mathrm{P}$ & Boro & 1188 & -0.14 & -2.15 & 11.72 & 12.57 & -1.26 & 10.19 & -1.50 & $-1.26 \mathrm{E}-1$ & -0.02 & $-1.41 \mathrm{E}-5$ \\
\hline ECIS-16 & Boro & A9918P & Boro & 906 & -1.17 & -4.29 & 4.98 & -8.42 & -15.55 & -12.37 & -0.68 & $-7.51 \mathrm{E}-2$ & 0.35 & $3.87 \mathrm{E}-4$ \\
\hline EGS-01 & Boro & EGS & Boro & 1188 & & & & & & & -0.44 & $-3.66 \mathrm{E}-2$ & -0.32 & $-2.69 \mathrm{E}-4$ \\
\hline EGS-02 & Boro & EGS & Boro & 1188 & & & & & & & -0.12 & $-9.90 \mathrm{E}-3$ & -0.29 & $-2.47 \mathrm{E}-4$ \\
\hline \multicolumn{15}{|c|}{ AET: DSET CPS Tabletop Exposure System \#3/ 1 UV sun/BPT $=80-85^{\circ} \mathrm{C}$} \\
\hline ECIS-05 & Boro & $15295 \mathrm{P}$ & Boro & 1186 & -0.42 & -1.94 & 13.33 & 11.44 & -3.17 & 9.32 & -1.13 & $-9.52 \mathrm{E}-2$ & 0.38 & $3.17 \mathrm{E}-4$ \\
\hline ECIS-17 & Boro & A9918P & Boro & 904 & -0.71 & -3.55 & 4.50 & 4.88 & -2.46 & 1.17 & -1.69 & $-1.87 \mathrm{E}-1$ & 1.68 & $1.86 \mathrm{E}-3$ \\
\hline EGS-03 & Boro & EGS & Boro & 1186 & & & & & & & -0.73 & $-6.14 \mathrm{E}-2$ & -0.23 & $-1.90 \mathrm{E}-4$ \\
\hline EGS-04 & Boro & EGS & Boro & 1186 & & & & & & & -0.76 & $-6.40 \mathrm{E}-2$ & -0.20 & $-1.65 \mathrm{E}-4$ \\
\hline \multicolumn{15}{|c|}{ AET: UV-enhanced Solar Simulator (UV-SS) \#2/ 7.5 UV suns $/ \mathrm{BPT}=85^{\circ} \mathrm{C}$} \\
\hline ECIS-06 & Boro & $15295 \mathrm{P}$ & Boro & 849 & -0.07 & -0.68 & 6.38 & 6.53 & -0.45 & 5.79 & -17.43 & $-2.05 \mathrm{E}+0$ & 26.76 & $3.15 \mathrm{E}-2$ \\
\hline ECIS-08 & Boro & $15295 \mathrm{P}$ & Boro & 1186 & -0.60 & 1.29 & 6.76 & 3.07 & -1.61 & 4.42 & -16.13 & $-1.36 \mathrm{E}+0$ & 24.23 & $2.04 \mathrm{E}-2$ \\
\hline ECIS-22 & Boro & A9918P & Boro & 870 & -2.70 & -3.85 & 2.91 & 8.04 & 3.73 & 3.84 & -9.28 & $-1.07 \mathrm{E}+0$ & 18.84 & $2.17 \mathrm{E}-2$ \\
\hline EGS-05a & Boro & EGS & Boro & 872 & & & & & & & -4.01 & $-4.60 \mathrm{E}-1$ & -0.04 & $-4.19 \mathrm{E}-5$ \\
\hline \multicolumn{15}{|c|}{ AET: Full Spectrum Solar Simulator (FS-SS) \#3/ 9.0 UV suns/BPT $1^{\circ}{ }^{\circ} \mathrm{C}\left(\mathrm{T}(\mathrm{EVA}) \sim 110-115^{\circ} \mathrm{C}\right)$} \\
\hline ECIS-09 & Boro & $15295 \mathrm{P}$ & Boro & 1082 & -1.14 & -2.07 & -16.11 & -17.79 & -2.90 & -19.46 & -50.43 & $-4.66 \mathrm{E}+0$ & 61.19 & $5.66 \mathrm{E}-2$ \\
\hline ECIS-10 & Boro & $15295 \mathrm{P}$ & Boro & 1082 & -2.55 & -4.40 & -16.90 & -18.02 & -3.25 & -21.62 & -45.14 & $-4.17 \mathrm{E}+0$ & 54.09 & $5.00 \mathrm{E}-2$ \\
\hline ECIS-18 & Boro & A9918P & Boro & 805 & -2.26 & 0.23 & -22.76 & -23.50 & 1.51 & -23.35 & -32.76 & $-4.07 \mathrm{E}+0$ & 38.68 & $4.80 \mathrm{E}-2$ \\
\hline EGS-06 & Boro & EGS & Boro & 746 & \multicolumn{6}{|c|}{ (Severe delamination in $250 \mathrm{~h}$ ) } & -3.79 & $-5.08 \mathrm{E}-1$ & 1.89 & $2.54 \mathrm{E}-3$ \\
\hline
\end{tabular}

${ }^{1}$ Boro: borosilicate of 3.175-mm thick.

${ }^{2}$ Commercial EVA formulation: Fast-cure EVA 15295P and slow-cure EVA A9918P, where P stands for silane-primed.

${ }^{3}$ EGS samples do not contain c-Si solar cells and are laminated single layer. 
Case 2. Spire's c-Si Cell Samples. The thin c-Si cells were used by Spire to fabricate lightweight PV modules, as described in detail by M. Nowlan et al. [2]. The c-Si cells were laminated between two layers of air-permeable Tedlar or Tefzel polymer films. In an earlier work, we reported studying various encapsulation schemes, including the polymer/solar cell/polymer configuration [3]. Upon AET in a DSET system, the film laminates were not discolored because of photobleaching of the EVA or silicone adhesive [3,4]. A few films wrinkled upon exposure, but no delamination was observed. Table 2-Part I summarizes the encapsulation materials for each of the samples, the changes in the I-V parameters, and the small net increase in \%T. As with the ECIS samples, the cells' I-V parameters also exhibit irregular changes. The most unusual observations are on cell samples D1-2 and D2-1 that were laminated with silicone adhesive and UV-transmitting Tefzel. The two cells showed, respectively, a $23 \%$ vs. $24 \%$ loss in $\mathrm{J}_{\mathrm{sc}}$, a $16 \%$ vs. $28 \%$ loss in $\mathrm{P}_{\max }$ (or efficiency), but a $5.0 \%$ vs. $6.6 \%$ increase in $\% \mathrm{~T}$. In contrast, the D1-2 and D2-2 cells that were also laminated with silicone, but with UV-screening Tedlar, did not show such large loss in efficiency.

Case 3. a-Si Minimodules. Table 2-Part II shows the encapsulation materials, changes in I-V parameters, discoloration, and delamination observed for the exposed a-Si minimodules. All polymer top-films (polyester and nylon) turned light yellow or a darker yellow. The top-film on two samples was delaminated from the a-Si layer, and the nylon top-film on another sample was substantially wrinkled. The a-Si minimodules degraded as expected upon light exposure. A larger decrease in $\mathrm{I}_{\max }$ and $\mathrm{P}_{\max }$ occurred on the sample laminated with a thicker (3.0-mil) UV-screening polyester. As with the Spire samples, the a-Si sample laminated with silicone adhesive showed an efficiency loss of $20.6 \%$, the largest of any cell.

The irregularity in the results presented in Tables 1 and 2 indicates that optical transmittance loss alone is not sufficient to explain the exact cause(s) or to pinpoint the electrical degradation mode(s) responsible for the cell efficiency changes upon AET treatments. To obtain a better interpretation, presently, we are performing detailed analysis of the dark/light I-V data to determine the changes in the series resistance $\left(R_{s}\right)$, shunt resistance $\left(R_{\text {sh }}\right)$, and diode quality factor $(n)$. Such analysis may be useful because the changes in the fill factor (FF) are also irregular, but mostly negative, suggesting an increase in the cell series resistance. The UV-transmitting Tefzel films may have permitted UV-induced photochemical reactions of the silicone adhesive and produced yet unidentified by-products that caused chemical degradation of the c-Si and a-Si cells and metallic components.

Case 4. Evergreen Solar's Thermoplastic Pottant. The AET results are shown in Table 1. When exposed in an oven in the dark or to $\sim 1 \mathrm{UV}$ sun at a black panel temperature (BPT) of $60^{\circ}-65^{\circ} \mathrm{C}$ or $80^{\circ}-85^{\circ} \mathrm{C}$ for $900-1200 \mathrm{~h}$, both EGS films and EVA remained clear. The thickness of the laminated EGS films is typically $\sim 10 \pm 2$ mil as compared to a thickness of $\sim 20 \pm 2$ mil for the EVA layer in the optical region of the ECIS samples. Assuming a linear \% $\%$ loss versus AET time for convenience, then the EGS film showed a slightly lower \%T loss rate than EVA (the thickness difference is not considered). Under more severe AET conditions using solar simulators, EVA 
TABLE 2. Change (\%) of I-V Parameters, Transmittance, and Adhesion for Encapsulated c-Si Cells and a-Si Minimodules by AET Treatments

Part I. AET: DSET CPS Tabletop Exposure System \#2/ 1 UV Sun/BPT $\sim 60-65^{\circ} \mathrm{C} / 1188 \mathrm{~h}$

\begin{tabular}{|c|c|c|c|c|c|c|c|c|c|c|c|c|}
\hline \multirow{2}{*}{$\begin{array}{c}\text { c-Si } \\
\text { Cell ID }\end{array}$} & \multirow{2}{*}{$\begin{array}{l}\text { Cell Thick- } \\
\text { ness }(\mu \mathrm{m})\end{array}$} & \multirow{2}{*}{$\begin{array}{l}\text { Top } \\
\text { Film }\end{array}$} & \multirow{2}{*}{$\begin{array}{c}\text { Pottant } \\
\text { Type }\end{array}$} & \multirow{2}{*}{$\begin{array}{l}\text { Bottom } \\
\text { Film }\end{array}$} & \multirow{2}{*}{$\begin{array}{l}V_{\text {oc }} \\
(\%)\end{array}$} & \multirow{2}{*}{$\begin{array}{l}V_{\max } \\
(\%)\end{array}$} & \multirow{2}{*}{$\begin{array}{l}\mathbf{J}_{\mathbf{s c}} \\
(\%)\end{array}$} & \multirow{2}{*}{$\begin{array}{l}\mathbf{J}_{\max } \\
(\%)\end{array}$} & \multirow{2}{*}{$\begin{array}{l}\text { FF } \\
(\%)\end{array}$} & \multirow{2}{*}{$\begin{array}{l}\mathbf{P}_{\max } \\
(\%)\end{array}$} & \multicolumn{2}{|c|}{ Transmittance $(\%)$} \\
\hline & & & & & & & & & & & $290-790 \mathrm{~nm}$ & $290-1500 \mathrm{~nm}$ \\
\hline A1-2 & $320+/-50$ & Tedlar* & $\mathrm{EVA}^{*}$ & Tedlar & -0.82 & -3.30 & 3.96 & -5.69 & -11.52 & -8.78 & 0.37 & -0.50 \\
\hline A2-2 & $125+/-25$ & Tedlar & EVA & Tedlar & -0.51 & -2.83 & 9.19 & 10.34 & -1.30 & 7.20 & 1.10 & 1.06 \\
\hline B1-1 & $320+/-50$ & Tefzel* ${ }^{*}$ & EVA & Tefzel & 0.00 & -1.26 & 4.63 & 6.04 & 0.12 & 4.74 & 2.14 & 1.53 \\
\hline B2-1 & $125+/-25$ & Tefzel & EVA & Tefzel & -0.36 & -2.32 & 7.30 & 8.02 & -1.35 & 5.48 & 1.57 & 1.26 \\
\hline $\mathrm{C} 1-2$ & $320+/-50$ & Tedlar & Silicone* & Tedlar & -0.59 & -3.51 & 6.39 & 10.82 & 1.10 & 6.90 & 1.09 & 0.52 \\
\hline $\mathrm{C} 2-2$ & $125+/-25$ & Tedlar & Silicone & Tedlar & -1.17 & -1.87 & 4.14 & -0.29 & -4.91 & -2.19 & 1.25 & 0.07 \\
\hline D1-2 & $320+/-50$ & Tefzel & Silicone & Tefzel & -1.04 & -0.65 & -22.69 & -15.43 & 9.90 & -15.95 & 6.60 & 3.75 \\
\hline D2-1 & $125+/-25$ & Tefzel & Silicone & Tefzel & -0.52 & -1.30 & -22.87 & -27.18 & -6.34 & -28.13 & & \\
\hline D2-1 & & Tefzel & Silicone & Tefzel & -0.24 & -1.30 & -25.46 & -27.71 & -4.08 & -28.66 & & \\
\hline \multirow[t]{2}{*}{ D2-1 } & & Tefzel & Silicone & Tefzel & -0.34 & 2.16 & -23.54 & -29.82 & -5.96 & -28.32 & & \\
\hline & & \multicolumn{3}{|c|}{ (3 measurements for D2-1): } & -0.36 & -0.14 & -23.96 & -28.24 & -5.46 & -28.37 & 5.01 & 2.67 \\
\hline
\end{tabular}

* The c-Si solar cells are laminated between $25 \mu \mathrm{m}$ UV-screen Tedlar or $25 \mu \mathrm{m}$ Tefzel with $90 \mu \mathrm{m}$ EVA or $50 \mu \mathrm{m}$ Silicone transfer adhesive

Part II. AET: DSET CPS Tabletop Exposure System \#1/ 1 UV Sun/BPT $\sim 60-65^{\circ} \mathrm{C} / 1235 \mathrm{~h}$

\begin{tabular}{|c|c|c|c|c|c|c|c|c|c|c|c|}
\hline $\begin{array}{c}\text { a-Si } \\
\text { Cell ID }\end{array}$ & $\begin{array}{l}\text { Area } \\
\left(\mathrm{cm}^{2}\right)\end{array}$ & $\begin{array}{l}\text { Top } \\
\text { Film }\end{array}$ & $\begin{array}{l}\text { Pottant/ } \\
\text { Adhesive }\end{array}$ & $\begin{array}{l}V_{o c} \\
(\%)\end{array}$ & $\begin{array}{l}V_{\max } \\
(\%)\end{array}$ & $\begin{array}{l}\mathbf{J}_{\mathbf{s c}} \\
(\%)\end{array}$ & $\begin{array}{l}I_{\max } \\
(\%)\end{array}$ & $\begin{array}{c}\text { FF } \\
(\%)\end{array}$ & $\begin{array}{l}P_{\max } \\
(\%)\end{array}$ & $\begin{array}{l}\text { Film } \\
\text { Color }\end{array}$ & Adhesion \\
\hline F57S6-1 & 20.65 & $\begin{array}{l}\text { PES* } \\
(1.5 \text { mil })\end{array}$ & $\begin{array}{l}\text { EVA } \\
(0.5 \text { mil })\end{array}$ & -1.81 & -4.68 & -9.38 & -3.83 & 3.04 & -8.34 & Light yellow & Delaminated \\
\hline F57S11-2 & 20.46 & $\begin{array}{l}\text { UV-PES } \\
(1.0 \text { mil })\end{array}$ & $\begin{array}{l}\mathrm{PE}^{*} \\
(2.0 \text { mil })\end{array}$ & -2.10 & -3.13 & -9.08 & -5.37 & 3.05 & -8.31 & Light yellow & Delaminated \\
\hline F57S18-3 & 20.67 & $\begin{array}{l}\text { UV-PES* } \\
(3.0 \mathrm{mil})\end{array}$ & $\begin{array}{l}\mathrm{PE} \\
(2.0 \mathrm{mil})\end{array}$ & -4.20 & -7.33 & -10.80 & -10.76 & -2.95 & -17.11 & Light yellow & \\
\hline F55S28-4 & 20.27 & $\begin{array}{l}\text { Nylon } \\
\text { (1.5 mil) }\end{array}$ & $\begin{array}{l}\text { Silicone } \\
(1.5 \mathrm{mil})\end{array}$ & -1.69 & -7.27 & -14.10 & -14.40 & -6.00 & -20.61 & darker yellow & Wrinkled \\
\hline
\end{tabular}

* PES: polyester; UV-PES: UV-screen polyester; PE: polyethylene thermal set adhesive. 
discolored to yellow-brown or dark brown, but the EGS film did not discolor. The \%T loss rates for the EGS films were 3-4 times less than the EVA when exposed to $7.5 \mathrm{UV}$ suns at a BPT of $85^{\circ} \mathrm{C}$ and was $\sim 8$ times less when exposed to $9.0 \mathrm{UV}$ suns at a BPT of $\sim 145^{\circ} \mathrm{C}$. In the latter conditions, however, the EGS film exhibited severe coral-like delamination from the borosilicate plate in $\sim 250 \mathrm{~h}$, which might have resulted from a melting point of $100^{\circ}-110^{\circ} \mathrm{C}$ for the thermoplastic material. Our results show the EGS films are photochemically stable against UV-induced browning, in good agreement with other results reported recently by Hanoka [5]. However, the EGS films may require improvement in the adhesion strength for their modules to operate at high temperatures.

\section{CONCLUSIONS}

We have reported the results of a series of AET studies for various Si cell samples that were encapsulated with different superstrates, pottants, and substrates. Irregular changes in the $\mathrm{J}_{\mathrm{sc}}, \mathrm{FF}$, and cell efficiency were observed for all tested c-Si cell samples, which cannot be simply attributed to the \% $\mathrm{T}$ loss of the superstrate/pottant. More detailed analysis of the light/dark I-V and electrochemical impedance data is under way. Different kinds of delamination were observed separately on a-Si minimodules and for EGS films at high temperatures. Silicone adhesives used under UV-transmitting polymer top-films seem to cause a greater loss in cell current and efficiency. The new pottant used by EGS may avoid adhesion failure and be a good pottant if the modules are not used at high operating temperatures. To continue the AET studies, we are preparing a large-scale "matrix experiment" using a large number of variously encapsulated c-Si cells for AWT in weatherometers. We are also investigating the issues of nonuniform EVA browning patterns observed in the ECIS samples.

\section{ACKNOWLEDGEMENTS}

The authors thank A. Czanderna and R. Hulstrom for their support of this work and K. Emery, H. Field, and D. Dunlavy for the assistance in the I-V measurements. This work was supported by the Department of Energy under Contract No. DE-AC36-83CH10093.

\section{REFERENCES}

1. Pern, F. J., "A Comparative Study of Solar Cell Performance under Thermal and Photothermal Tests," Proc. PV Performance and Reliability Workshop, Sept. 16-18, 1992, Golden, CO, pp. 327-344.

2. Nowlan, M. J., Maglitta, J. C., and Lamp, T. R., "Lightweight Photovoltaic Modules Development for Unmanned Aerial Vehicles," presented at $33^{\text {rd }}$ Intersociety Engineering Conference on Energy Conversion, IECEC-98-1253, Colorado Springs, CO, Aug. 2-6, 1998.

3. Pern, F. J. and Glick, S. H., "A Study of Various Encapsulation Schemes for c-Si Solar Cells with EVA Encapsulants," Conf. Proc. \#394 for the $14^{\text {th }}$ NREL/SNL National PV Program Review Meeting, C. E. Witt, M. Al-Jassim, and J. M. Gee, ed., AIP, New York, 1997, pp. 811-824.

4. Pern, F. J., Solar Energy Materials and Solar Cells, 41/42 (1996) 587-615.

5. Hanoka, J. I., "A New Encapsulant Material for Photovoltaic Modules," presented at the $2^{\text {nd }}$ WCPSEC $/ 27^{\text {th }}$ IEEE PVSC, Vienna, Austria, July 6-10, 1998. 